\title{
NATURE FRESERVATION AND NATIONAL PARK PROBLEMS IN JAPAN
}

(Addressed at Recreation Section, Pan-Pacific Conference on Education, Rehabilitation, Reclamation and Recreation, Honolulu, T.H. U.S. A., April 14, 1927)

\section{By Keiji Uyehara, Dr. F.,}

Official Delegate from Japan and President of Japanese Landscape Architectural Society, Inc.

The necessity for nature preservation in Japan was neglected for a long time, and it was not until rgrg that there began to be activity in this field. The first nature preservation law was created in r 919 by the Department of Home Affairs. This Iaw set aside sevsral regions for preservation, but not for national park purposes, and they were indifferently managed by an ineffective force.

This law is called "Law of Preserving Historic, Scenic and Natural Monument" and at the last section of it the regulation concerning the natural preserved district was enacted.

I think, to my curiosity, the duration 1615 -1920 five or six years are the golden ages in landscape architecture in the world, when most of valuable books of this specialities were published, most of cooperative organizations of this science were created, most of wonderful landscape designs were made.

The national park movement also came to birth not so long ago. These two problems effect the promotion of nature study, national health and out-door recreation, and must at the same time be recognized as important activities in our modern civilization.

The dawn of this movement is not so many years ago; before 1920 this term was not so widely used except in landscape architects group, and in that year I delivered a short address on the subject of "Internationalization of Scenic Beauty and National Park" just before my departure for America. 
Japan was rather slow to take up problem of nature preservation, confidently believing that the natural beauty of our vast stretches of country was inexhaustible, and indestructible even by the savagery of civilization.

The first national park proposal to the Imperial Diet was at least sixteen years ago (I9II). Recent proposals for the setting aside of such parks have totaled eighty, during the period from the forty-fifth to the fifty-second session (1927) of our House of Representatives. These proposed park sites and acerages cover almost all of our country regions of natural beauty, historic interest or special note. They would make all Japan a park, I might say! This movement was given great impetus in 1920 and $192 \mathrm{I}$, at which time I went to America to study similar systems there.

The case of rgr proposal was to be elected Nikko National Park. All cases of proposed national parks from forty-fourth to fifty-second session are as follows, pointing southward from north. At Hokkaido......Lake Shishaku, Jozan-Kei Valley, Noboribetsu Hot-Springs, Nopporo.

At Mainland.........Lake Towada, Matsu-Shima Sea View, Hachiro Inlet, Lake Inawashiro, Azumayama, Mt. Asama, Nikko, Chichibu Range, Mt. Tsukuba, Mt. Kano, Itako Sound, Mt. Akagi, Mt. Myogi, Mt. Haruna, Mt. Takao, Tama, Kamakura, Mt. Fuji, Lake Hamana, Kamikochi, Mt. Tachiyama, Kurobe, Yoro Fall, Awaji Island, Mt. Yoshino, Waka-no-ura Sea Shore, Lake Biwa, Mt.Koya, Vicinity of Kyoto, Miyajima, Seto Inland, Izumo Shrine and Vicinity, etc.

At Kyushu-Mt. Aso, Mt. Kirishima, Matsu-ura.

At Korea-Mt. Kongo.

'They contain lake, hot-springs, virgin forest, valley, see shore, inlet river, mountain, place of historic and special note, alpine region, water-fall.

Let us, however, consider this movement rationally. There will 
be found to be many differences in conditions in the United States of America, Canada, Switzerland and Japan. In original conception and motive for establishing the national park, there should be three purposes: education, nature preservation and recreation. Of these three which may be regarded as the most important, or as preferable for first attention? Are they not, rather, cooperative purposes, in this field of work? We may be able in classification in another way, but the necessary essence is always the same. This is the most important point of view to be considered. In America, you will say, a certain region will be spoiled, unless it is set aside as a park, shortly a place can be preserved only by setting aside as a park. In Japan this fact is sometimes on the contrary.

We must not permit the deterioration of nature, nor await the time when beauty of scene becomes spoiled through being devoted to recreational life only. Even though the vital need for such recreation be recognized as a dominant one in our civic life, it must not be made so at the expense of natural beauty. On the other hand, world-famed regions which are suitable for national parks should be open to the public for recreation. Such is public opinion, regarding this as the privilege of all classes of peple. This use of nature in modern city life is being sought more and mare eagerly and used more extensively than ever before. It has become an indispensable factor, yet it has never been submitted to systematic analysis to determine its proper relationship to other factors, or its best mearo of development. The same is true of the scope of nature viewed from the standpoint of education.

In solving such questions as these, which will arise from an analysis of the highest uses to which nature may be put, there will be some differences in the various countries. These differences in solving the problem will depend upon differences in nationality, culture, civic life, customs and manners, general ideas as to nature, climate, transportation facilities, etc. 
There are two great dangers to be recognized. One lies in the increasing floods of people who go mountaineering, particularly in summer time, without any idea of the value of nature, and without using foresight regarding her preservation. The other danger lies in the growing unreasonable demand for economic uses of nature water-power, road-cutting, deforestation, home industry in some places. It is certain that we are approaching a time when we will no longer be in a position to destroy natural beauties, for there will be no more beauty left to destroy. People should wake up to the fact that something has to be done before it is too late.

We must now establish system and organization in nature protection, and carefully make plans and arrangements for the work. Of course, in recent years, some attempts have been made by various local authorities with private cooperation, and with such facilities as were available, but not by the government. Now the government should systematize and coordinate the work.

The real meaning of the term "National Park" is interpreted differently in every country. In Switzerland, although both this term and that of "Naturschutzpark" are used, there is no recreational meaning included. For instance, at Unter Engaden people are excluded from all uses of nature in the park there. In Germany they use the term "Naturgebiet" or "Naturschutzgebiet," and "National Park" is not used.

In Japan we do not yet have such parks, but as the term has been introduced and circulated widely, we must define an adequate meaning from the standpoint of our own conditions. This is difficult to do, but must be accomplished, as there exists much misunderstanding concerning it, even among cultured classes of people. Defininition should not be confined closely within the idea of rereation only.

It may be seen from the forgoing that an idea concerning the real spirit of the national park needs to be stimulated in Japan. 
In this conception of the park there are two elements to be considered-one from the point of view of public activities, and one governmental activities. In other words, one a " nation's park for recreation proper"; the other, "nature preservation for scientific research and enjoyment and, moreover, for the educational effect of nature study upon the present and the coming generation"; both of which need federal efforts. Of these two, under present circumstances the latter seems preferable to the former, I think; but they should be made to cooperate perfectly in the future Japanese national park.

Our government and responsible local authorities should compose the differences between these two contrary phases-the destruction which grows out of recreational use, and preservation for research and enjoyment.

The Japanese Government gives us three bureaus for park management. First, the city park control, under the city-planning act, belongs to the City Planning Bureau of the Department of Home Affairs. Second, provincial, prefectural and local parks come under the Sanitary Bureau of the same Department. Third, regions set aside for nature protection, "Naturscnutzgebiet" (not strictly parks) come under the Bureau of Domain of the same Department.

Then what is the best way to administrate the further national park system in Japan, after such organization will be created. As for this subject, I can not state as an official delegate. As the first step, owing to my opinion as a personal capacity, it is to be constituted the national park committee consisting several experts, governmental officers from various Department-Department of Home Affairs, of Education, and Agriculture and representatives of public and private incorporations concerning this branch. They are to cooperate together for its accomplishment. In the other hand, some of the places proposed for such parks are to be investigated from the said standpoints above described and moreover, general 
idea as to the nature atudy must be developed more eagerly by school and social education among peoples, and let them know the real value of preservation.

Secondarily the park law should be enacted in this commission.

Our government recognized definitely the necessity for such park systems and public organization, but the national fund available for this purpose is not sufficient under present financial conditions. Natural beauty, however, may be considered as capital and utilities, and visiting guests to park preserves may be regarded as the interest on the capital.

It is sincerely hoped that such a system can be built up whereby the exact uses of parks may be defined, and such intensive uses of nature developed as we have not heretofore known. This may be brought about, we trust, by concerted action, the cordial help of government efforts, favorable public sentiment, and the aid of the United States of America,- “ United States is the pioneer in the park movement. We are the first government that has inaugurated a policy of national parks-Japanese government is one of the governments that solicited from our government information about those things" as Mr. John J. Tigert, Commissioner of Education of United States, has said.

Bryant said "To him who in the love of nature holds communion with her visible forms, she speaks various languages."

With these few words I make my conclusion. 